\title{
The cost of water and water markets in Southern California, USA
}

\author{
W. G. Hamer \\ Geomatrix Consultants, Inc, Newport Beach, California, USA
}

\begin{abstract}
It is surprising to learn what people pay for water in Southern California. Of course, it depends on what you need the water for, when you need it, and where it comes from. Rates for the least expensive water, for agricultural use, are $\$ 15$ $(€ 12)$ or more per acre-foot $\left(1,230 \mathrm{~m}^{3}\right)$. The highest-cost wholesale water is desalinated seawater at a cost of $\$ 800$ to $\$ 900$ per acre-foot (AF). The base treated and untreated water rates for the largest wholesale water purveyor in California, Metropolitan Water District of Southern California, are \$371 and $\$ 478$ per $A F\left(€ 232\right.$ and $€ 300$ per $1000 \mathrm{~m}^{3}$ ). Actual rates paid by water districts for Metropolitan water vary depending on the type of service and the costs to deliver the water to the service location.

Residential water rates in California, which include delivery and service charges, averaged $\$ 905$ per AF in $2005\left(€ 567 / 1000 \mathrm{~m}^{3}\right)$. The average residential user in 2005 required $0.4 \mathrm{AF}\left(490 \mathrm{~m}^{3}\right)$ of water for the year. Residential water rates have increased over the last 15 years, from approximately $\$ 20(€ 15)$ per month in 1991 to approximately $\$ 35$ (€27) per month in 2005, representing an average annual increase of $3.8 \%$.

As the need for reliable water supplies increases so does the cost. Informal and formal water markets are increasing. Markets for permanent water rights and annual water rights have been incorporated into recent legal judgments for groundwater basins in Southern California. Water markets are helping to reduce over pumping of groundwater basins. They promote better planning for droughts, water conservation, and increased water system reliability.

Keywords: water cost, water markets, water rates, water supply, California water.
\end{abstract}




\section{Introduction}

As major cities have developed in Southern California, the costs that citizens have paid for water have risen steadily. Competition for ever-scarcer low-cost reliable supplies is growing, and as a result, costs are increasing.

Despite appearances to the contrary, there is enough water to meet the needs of Southern California residents and industry. Half of the water used in California is used to water just four crops: irrigated pasture, alfalfa, cotton, and rice! [1]. Overall, agriculture consumed more than $80 \%$ of water used in California in 1990. In 1990, the director of the California Water Resources Center observed: "We've still got plenty of water. It's just misallocated." [2].

The question is how much will adequate, reliable water supplies cost Southern California residents? Water supplies are often discussed in terms of environmental, social, and financial costs. This paper focuses on the financial costs for water in Southern California. The overall range in costs for water is discussed along with information regarding imported and retail water costs. Some historic information is also presented to provide perspective on the changes in costs in recent years. Additionally, recent creative efforts by water suppliers are also discussed, with special emphasis on the water market in the Mojave River drainage, in San Bernardino County, California.

\section{General factors affecting the cost of water}

The cost of water varies widely, depending on many factors. Just ask anyone in the water supply industry about his or her water costs, and it quickly becomes obvious that the subject is a complex and dynamic one, with costs based on many factors. You're likely to hear a wide range in costs and answers, ranging from bulk water costs to pumping costs, to complaints about their monthly water bill! The more significant factors include the following.

- $\quad$ Potability. Whether or not the water is treated or treatable for potable use is a key factor. Surface waters must be treated for potable use. Reclaimed water, although treated, is not currently accepted for potable use. (There is an aversion to using water that is "Toilet to tap").

- $\quad$ Location. The point of use has a significant impact on the cost of water. Pumping and distribution costs may be a significant factor in what the user pays for water.

- $\quad$ Volume. The volume of water required ranges from bulk water to bottled water.

- $\quad$ Reliability. The reliability of the supply, both on a seasonal and long-term basis has a significant effect on the overall cost.

- $\quad$ Power costs. In most cases, power costs for pumping and distributing water are the most significant component in the rate paid by the user.

These various factors are discussed below as they relate to the types of waters consumed in Southern California. 


\subsection{The cost of bulk (wholesale) water}

Bulk or wholesale water is considerably lower in cost than potable water delivered to individual residential or industrial users. Bulk water supplies are primarily surface waters, including imported aqueduct water and local surface waters. Distribution costs, which may be significant, are much less for bulk water.

The lowest-cost water in Southern California is agricultural water. In the Imperial Valley, and in parts of the Central Valley, farmers pay as little as $\$ 15$ per acre-foot (AF) for irrigation water $\left(€ 9 / 1000 \mathrm{~m}^{3}\right)$. As recently as 1990 , subsidies resulted in farmers obtaining untreated Central Valley Project water as cheaply as $\$ 3 / \mathrm{AF}\left(€ 1.9 / 1000 \mathrm{~m}^{3}\right)$, and from the California State Water Project (SWP) aqueduct as cheaply as $\$ 62 / \mathrm{AF}\left(€ 39 / 1000 \mathrm{~m}^{3}\right)$ [3].

Local Groundwater is often pumped for farming use at a cost in the range of $\$ 40$ to $\$ 60 / \mathrm{AF}$ ( $€ 25$ to $€ 37 / 1000 \mathrm{~m}^{3}$ ). Because groundwater in many cases does not require treatment to be potable, the only cost to the user is the pumping cost, which is governed primarily by the cost of power.

Imported water supplies vary considerably in cost. Water imported for use in Southern California travels via one of three aqueduct systems: the SWP, the Colorado River Aqueduct (CRA), and the Owens River Aqueduct. These imported water supplies, being surface water, require treatment prior to their use as potable water. The price that agencies pay for regular supplies from these aqueduct systems ranges from $\$ 148$ to more than $\$ 570 / \mathrm{AF}$ (€93 to $\left.€ 360 / 1000 \mathrm{~m}^{3}\right)[4,5]$.

The SWP also offers supplemental water that is periodically available. This mechanism for obtaining supplemental waters acts as a type of basic "water market". An example of the buying and selling of water in this manner is the California Department of Water Resources" "water bank" where farmers and agencies that do not need their full water entitlement allow the state to sell the available water to cities and water agencies.

In recent years, technological improvements have caused the costs for desalinization of sea water to decline. Recent estimates for the Orange County Water District for a large-scale desalinization plant (60 million gallons or $180 \mathrm{AF} /$ day) are approximately $\$ 900$ to $\$ 1200 / \mathrm{AF}\left(€ 560\right.$ to $€ 750 / 1000 \mathrm{~m}^{3}$ ). The West and Central Basin Municipal Water District operates a desalinization test program. They estimate the cost of seawater desalinization at approximately $\$ 900 / \mathrm{AF}$. To encourage desalinization, Metropolitan has offered a subsidy of $\$ 250 / \mathrm{AF}$ for up to $50,000 \mathrm{AF} /$ year of seawater desalinization. This subsidy would reduce the cost to $\$ 650 / \mathrm{AF}\left(€ 410 / 1000 \mathrm{~m}^{3}\right)$; in the range of some other potable water supplies.

Lastly, reclaimed water is becoming an increasing source of supply. Reclaimed municipal wastewaters are being sold for a variety of non-potable uses, primarily landscape irrigation. In the Coachella Valley, reclaimed water is sold by the Desert Water Agency for $50 \%$ of the potable water cost, or approximately $\$ 150 / \mathrm{AF}\left(€ 95 / 1000 \mathrm{~m}^{3}\right)$. In Orange County, reclaimed water is 
sold by the Irvine Ranch Water District for 10 to $20 \%$ less than potable water [6].

\subsection{The cost of retail water}

The price that a Southern California homeowner pays for water varies considerably. At a glance, significantly higher rates in one area than in another may seem unreasonable. This may not be the case, however. The setting of retail water rates is a complicated process, based on many factors. The factors affecting water rates in an area include the following.

- $\quad$ Sources of funds used by and available to a utility. Sources may be retail water sales, monthly service fees, and property taxes.

- Geographical factors. These include the distance to any imported water sources, and the size and elevation differences within the service area.

- Rate design. This includes the costs involved in operating the water system and the means to fund them. For example, an older water system may require higher rates to pay for system improvements.

- Reserve funds. Rates may include costs for the utility to maintain a reserve for funding growth or debt service.

Retail water rates are commonly stated in cost per "hundred cubic feet" (\$/ccf). In order to compare retail rates with wholesale or bulk water rates, retail rates are expressed below in $\$ / \mathrm{AF}$. Because all water rates, both wholesale and retail are made up of many complex factors, comparisons should be considered only general in nature. Water rates and consumer connection fees have increased in recent years as the result of increasing demand and to an aging infrastructure and rising construction costs [6].

From 2003 to 2006, the average residential monthly charge, for 1500 cubic feet $\left(42 \mathrm{~m}^{3}\right)$ of water per month, increased from $\$ 30.33$ to $\$ 36.39$ ( $€ 23,33$ to $€ 28)$. This is a total $17 \%$ increase during the three-year period.

\section{A water market helps control water costs and use}

Over pumping of groundwater in the Mojave River Basin (Basin) in the Mojave Desert of Southern California resulted in the legal adjudication of groundwater rights in the Basin and development of a water market. The water market is helping to reduce groundwater pumping and to provide for importing water to recharge the groundwater in the area. Costs for buying and selling water rights on the water market are increasing as limited water supplies are needed to meet increasing demands.

The Basin is approximately $9900 \mathrm{~km}^{2}$ in area. Most of the area is very dry, receiving only an average of four to 5 inches $(10$ to $12 \mathrm{~cm})$ precipitation per year. 
Summer temperatures are very high; the mean annual maximum temperature in the Basin is approximately 27 degrees centigrade $\left({ }^{\circ} \mathrm{C}\right)$.

Rapid population growth has resulted in intensive use of the aquifers in the area. The population growth rate from 1960 to 2000 was approximately $5,5 \%$. From 1990 to 2000 the population in the basin has increased from about 243000 to 290000 people and water demand has increased by approximately $5 \%$ per year. The increasing population has caused the water use in the Basin to shift from predominantly agricultural use to predominantly municipal use. The percentage of agricultural use continues to decline as the population increases.

In the Basin, groundwater is the primary source of water supply for communities, farms, and industry and groundwater extractions have greatly exceeded the safe or sustainable yield of the aquifer system in the basin. The safe yield is the amount of groundwater that can be produced from a basin or subarea on a long-term basis without a reduction in the amount of water in storage and without adverse effects on the resource. The Safe Yield for the Alto Subarea of the Basin is $69900 \mathrm{AF} /$ year $\left(56,6 \mathrm{~mm}^{3} /\right.$ year). The amount of groundwater that had been pumped from the subarea during the early 1990s (the Base Annual Production, or BAP) was $122400 \mathrm{AF} /$ year $\left(99,2 \mathrm{~mm}^{3} /\right.$ year). The pumpage had been greater than the Safe Yield and the area is severely overdrafted and groundwater levels declining.

For the Basin as a whole, approximately two-thirds of the groundwater consumptive use is for urban uses (municipal and industrial). The remaining one-third is agricultural use.

\subsection{The Mojave Basin Judgment}

As groundwater levels declined in the Basin, water users sued each other to protect their water rights, and the matter went to Court. In determining the best course of action, the Court had to consider how best to balance the legal rights and needs of agricultural interests in the basin and the water demands of a rapidly growing population. Many of the farms in the area had long histories of pumping groundwater for irrigating crops, including alfalfa, and various fruits and vegetables. The farmers felt that the growing population centers were threatening their water rights and ability to pump groundwater at relatively low cost. The Court had to find a solution that was acceptable to all of the primary water interests, including farmers, land developers, cities, water districts, and small water users. In doing so, the Court had to provide an incentive to farmers to accept the agreement, and an assurance that their long-standing water rights would be protected. Final legal challenges to the legal Judgment were settled in July 2002, including the ability for farmers to sell or lease their water rights if they chose to, and a payment of approximately $€ 385000$ (\$500000) to agricultural interests.

The final Judgment: (1) Established a Basin Watermaster to oversee groundwater pumping in the Basin and to administer the legal Judgment, (2) Established a Safe Yield for the Basin, which is the amount of groundwater that can be produced from a subarea on a long-term basis without a reduction in the amount of water in storage and without adverse effects on the resource. 
(3) Assigned a Base Annual Production (BAP) amount to each major groundwater producer. The BAP is a right to pump a certain amount of water every year in perpetuity. (4) Assigned a Free Production Allowance (FPA) to each major groundwater producer. The FPA is based on the BAP for the producer and the total for the subarea. The FPA is the amount of groundwater that a major producer can pump in a given year without paying a penalty fee to the Mojave Water Agency. (5) Established a class of "minimal users" who pump only minor amounts of groundwater and who are not subject to the Judgment.

The Judgment requires that the FPA for each producer be reduced over time so that the total amount of water pumped in a subarea is consistent with the Safe Yield of the subarea. Eventually, the total FPA for each subarea must approximately equal the safe yield of the subarea. The FPA reduction is controlled by the Watermaster. Each year, the Watermaster reviews the difference between the amount of groundwater pumped in a subarea and the Safe Yield of the subarea. If the amount of production is greater than the Safe Yield, the FPA is reduced by $5 \%$ for each major groundwater producer. The reduction in FPA is reviewed every year and the FPA is reduced until a maximum reduction to $60 \%$ is reached. Figure 1 summarizes this reduction in FPA for the Alto Subarea. As of 2005, the Alto Subarea FPA had been reduced to $60 \%$ of its original BAP. In the future, the FPA may be further reduced. Currently, the FPA is approximately the same as the Safe Yield for the Alto Subarea, helping to bring the subarea demand into balance with the long-term water supply.

The Judgment recognizes that some major producers may pump more groundwater than allowed by the Judgment. For example, this might occur if a water district has a significant increase in the number of people it serves. If a major producer pumps more groundwater than his FPA allows, he can do several things.

1) He can purchase unused FPA from another producer. For example, if a major producer such as a city or water district pumps more water than allowed by his FPA, he can purchase water from a farmer in the same subarea who did not use his entire FPA. A purchase of this type is only good for one year's pumping, and purchases must be made every year that the FPA is exceeded.

2) He can buy a certain amount of BAP from another producer. Once a certain amount of BAP is purchased, it can be used to pump water in perpetuity. This type of purchase costs more, however, it represents a permanent right to pump, not just a right for a single year.

3) He can pay the Watermaster a fee for each AF $\left(1230 \mathrm{~m}^{3}\right)$ pumped in excess of his FPA. The Watermaster will then take this money and use it to purchase imported SWP aqueduct water and recharge it in the appropriate subarea. For the 2004-2005 water year, the payment was \$262/AF $\left(€ 164 / 1000 \mathrm{~m}^{3}\right)$. 


\subsection{Water market established}

The Judgment established a method for the transfer (buying and selling) of both FPA and BAP within each subarea of the Mojave River Basin. The Watermaster tracks these transfers. When a major producer exceeds his FPA and does not purchase FAP or BAP from another producer, the Watermaster collects the fee required for overproduction $[8,9]$.

During the ten years since the Judgment was first established, there have been many changes in the water market. As anticipated by the Court, overproduction by some users has resulted in the purchase of FPA and BAP from other users in each subarea. These transfers have been tracked by the Watermaster. The number of FPA and BAP transfers has been largest in the Alto Subarea where the population growth and intensive use of the groundwater aquifers is the greatest. In the 2004-2005 water year, there were more than 240 transfers in the Alto Subarea. For this reason, the discussion below focuses on the Alto Subarea.

Three main conditions have affected the number of transactions and the amount of money paid for both FPA and BAP rights. These conditions, described below, are: 1) the reduction in FPA, 2) a shift in water use from agricultural to municipal and industrial use, and 3) increased stability in the water market as challenges to the Judgment have been settled.

The reduction in FPA as shown on Figure 1, means that the amount of FPA available to be bought and sold through the water market is declining. At the same time that the FPA is being reduced, the future water demand will increase. The recent and future water demands are shown on Figure 2. Figure 2 shows the percentage of agricultural and municipal and industrial (M\&I) pumping of groundwater in recent years. In 1996, when the Judgment was first issued, agricultural pumping was $60 \%$ of the total amount of groundwater pumped. M\&I use was $40 \%$. Also in 1996, approximately $50 \%$ of the total FPA for the Alto Subarea was not used.

\section{Mojave Basin Alto Subarea}

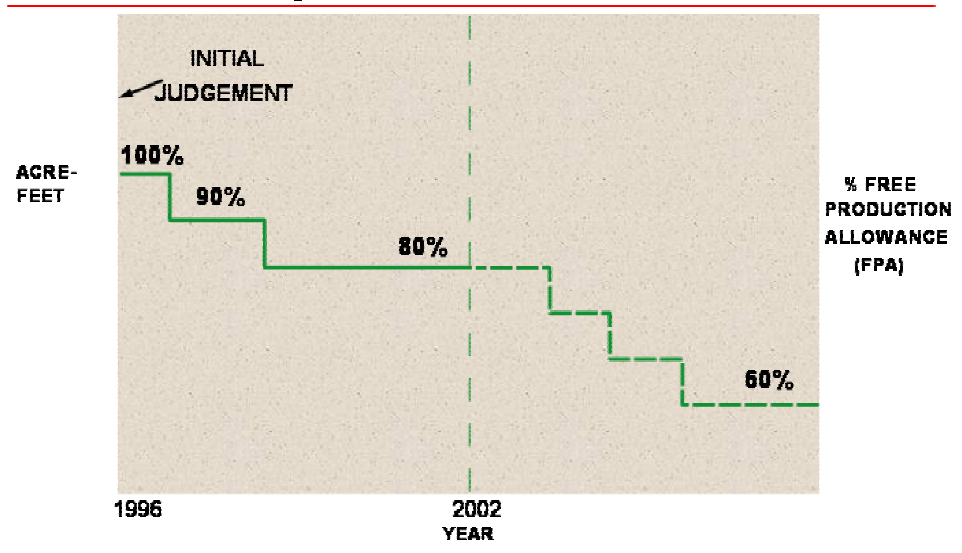

Figure 1: $\quad$ Reduction in free production allowance. 


\section{Mojave Basin Alto Subarea}

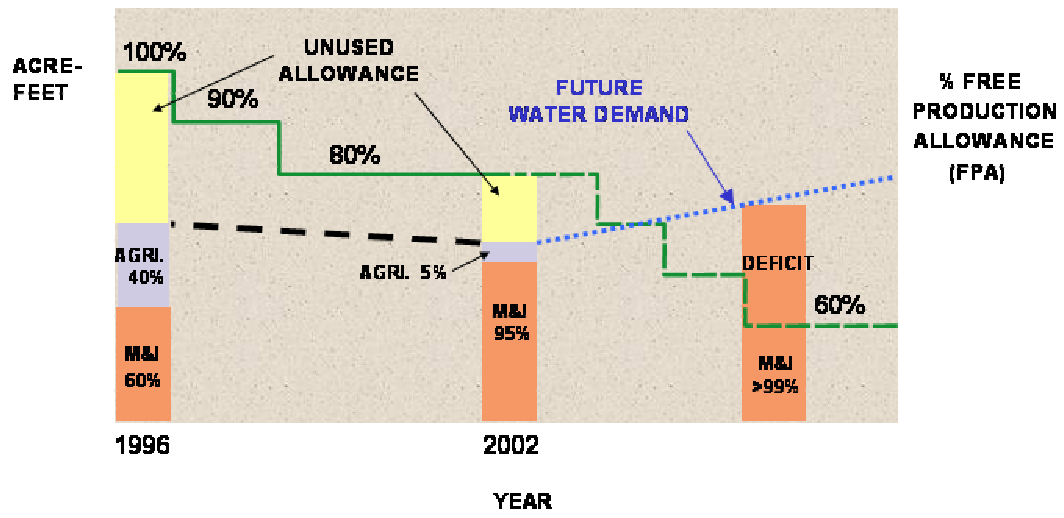

Figure 2: $\quad$ Shift in use and increased demand.

By the year 2002, agricultural pumping had declined to only 5\% of the total pumpage Pumping for M\&I use had increased significantly, as the result of population growth, to $95 \%$ of the total amount of water pumped. The amount of unused FPA has declined to approximately one quarter of the total allowed FPA for the Alto Subarea. The shift in water use from agricultural to M\&I is expected to continue into the future as the cities in the area grow, and as farmers reduce the size of their farms and sell their FPA or BAP allowances to other users. In the future, M\&I water use will most likely be greater than $99 \%$ of the water demand in the Basin. This trend suggests that the Judgment is working as planned, to allow farmers to reduce their groundwater pumping and sell their unused FPA or BAP. This allows farmers to make a profit on their water rights if they would like to.

As shown on Figure 2, since 2002, as the FPA was reduced to $60 \%$ of its original amount, the water demand has been greater than the FPA. This results in a deficit, where there is not enough FPA available for the major producers. The reduced availability of FPA results in increased competition for FPA and BAP rights.

Figure 3 shows the cost of both FPA and BAP in 1996 and in 2002. At the time of the initial Judgment (1996), a major producer could buy FPA for approximately $\$ 30 / \mathrm{AF}\left(€ 24,3 / 1000 \mathrm{~m}^{3}\right)$ and a BAP right for $\$ 800$ to $\$ 1000 / \mathrm{AF}$ $\left(€ 650\right.$ to $€ 770 / 1000 \mathrm{~m}^{3}$ ). In 2002 , the cost for buying FPA had almost tripled to $\$ 80 / \mathrm{AF}\left(€ 64,8 / 1000 \mathrm{~m}^{3}\right)$ and BAP rights increased to $\$ 1350 / \mathrm{AF}\left(€ 850 / 1000 \mathrm{~m}^{3}\right)$. In 2005 the cost had increased even more with BAP right as much as $\$ 2500 / \mathrm{AF}$ $\left(€ 1570 / 1000 \mathrm{~m}^{3}\right)$. 


\section{Mojave Basin Alto Subarea}

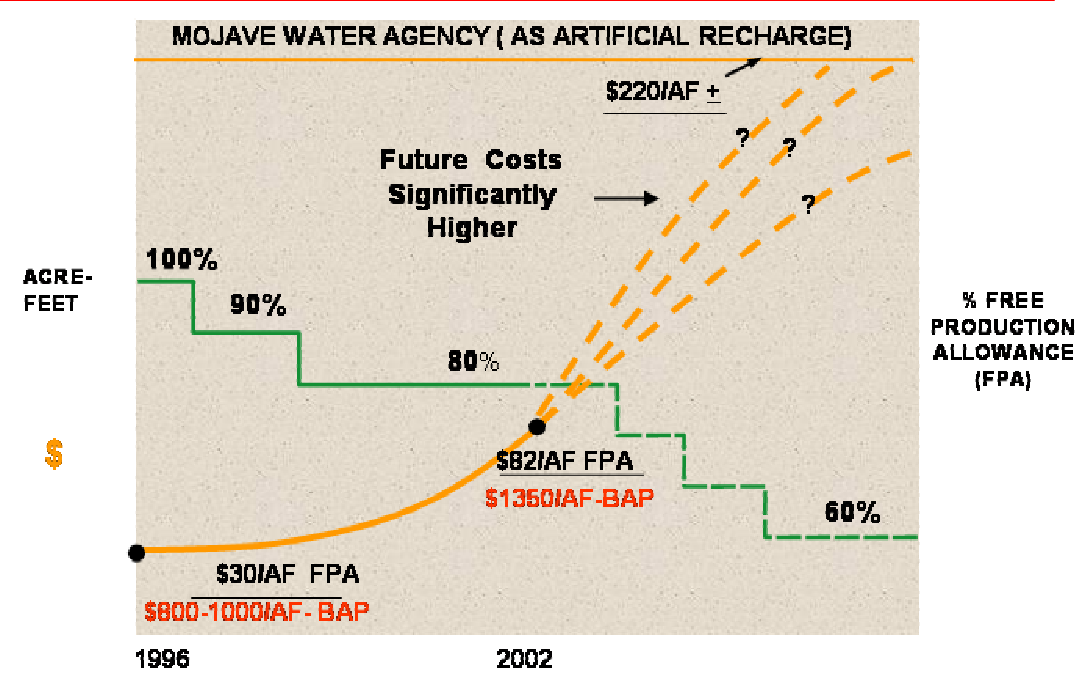

Figure 3: Increasing FPA and BAP prices.

In the past, if a major producer pumps more than his FPA, it has been cheaper to purchase unused FPA from another major producer rather than to pay the Watermaster an even higher fee. As a result, the MWA had only received a very few payments for purchasing water from the California SWP aqueduct and recharging it into the groundwater basin. However in recent years, the Watermaster has been able to collect more money and has begun recharging larger amounts of SWP water.

In the future, however, as shown on Figure 3, the water demand will exceed the available FPA and future costs will be significantly higher. The cost for one major producer to buy FPA from another major producer will increase until it consistently reaches or exceeds the same price as the Watermaster fee. Figure 3 shows the 2002 cost of $\$ 220 / \mathrm{AF}\left(€ 180 / 1000 \mathrm{~m}^{3}\right)$. At that time, the costs for buying FPA from other producers was less than the Watermaster's fee.

Currently and in the future, when FPA prices are too high, major producers will begin to pay the Watermaster for imported water. At that time, the Watermaster will have the funds to buy imported water and artificial recharge to the Basin will increase. The Mojave Water Agency, who acts on behalf of the Watermaster, has an imported water entitlement of up to $75800 \mathrm{AF} /$ year $\left(94 \mathrm{~mm}^{3}\right.$ per year) from the SWP. The SWP aqueduct crosses part of the Alto Subarea and water can be purchased, up to the entitlement amount, and recharged to the aquifer. This artificial recharge will be an important source of water supply to the overdrafted and intensively used aquifers in the Basin. The $94 \mathrm{~mm}^{3}$ of water that may be potentially recharged would increase the Safe Yield of the Basin from 
approximately $110 \mathrm{~mm}^{3}$ to more than $200 \mathrm{~mm}^{3}$ per year, almost doubling the Safe Yield of the basin. The increased availability of water will come at a price, as users must pay more for the right to pump water. As water costs increase, however, the Mojave River Basin water market will work to make water use more efficient; benefiting all water users in the Basin.

\section{Conclusions}

As the growing population in Southern California places increasing demands on local and imported water resources, the cost of water supplies will continue to increase. In order to maintain reliable and reasonably priced water supplies for their customers, water managers will need to look toward increased integration of imported, surface water, and groundwater supplies, including wastewater reclamation and seawater desalination. Factors such as climate change and population increases in Northern California and other parts of the American Southwest will also place greater demands on available water supplies and the amount of imported water available to Southern California.

Southern Californians have a long history of innovative approaches to meeting water supply challenges; including conjunctive use of surface and groundwaters, sea water intrusion barriers to protect aquifers, and seawater desalination. Creative solutions such as water markets and legal management of scarce resources will continue to increase water use efficiency while providing reliable cost-effective long term water supplies.

\section{References}

[1] Hundley, N. Jr., 2001, The Great Thirst, University of California Press, pages 465-466.

[2] Hundley, N. Jr., 2001, The Great Thirst, University of California Press, page 466.

[3] Hundley, N. Jr., 2001, The Great Thirst, University of California Press, page 467.

[4] California Department of Water Resources, 2005, Management of the California State Water Project, Bulletin 132-04, September.

[5] Metropolitan Water District of Southern California, 2006, Regional Urban Water Management Plan.

[6] Municipal Water District of Orange County, 2001, Water Rates, Water System Operations, and Financial Information, 2001.

[7] Black \& Veatch Company, 2006, 2006 California Water Rates Survey.

[8] Mojave Basin Watermaster, 2006, Watermaster Annual Report for Water Year, 2004-2005, April 1, 2006.

[9] Mojave Water Agency, 2002, Summary of the Judgment after trial, www.mojavewater.org. and Regional Water Management Plan Update, Phase 1 Report, June 2002. 